Cornell Law Library

Scholarship@Cornell Law: A Digital Repository

Cornell Law Faculty Publications

Faculty Scholarship

$4-1972$

\title{
A Comment on Trial-Type Hearings in Nuclear Power Plant Siting
}

Roger C. Cramton

Cornell Law School, rcc10@cornell.edu

Follow this and additional works at: http://scholarship.law.cornell.edu/facpub

Part of the Administrative Law Commons, and the Energy Law Commons

\section{Recommended Citation}

Cramton, Roger C., "A Comment on Trial-Type Hearings in Nuclear Power Plant Siting" (1972). Cornell Law Faculty Publications. Paper 944.

http://scholarship.law.cornell.edu/facpub/944

This Article is brought to you for free and open access by the Faculty Scholarship at Scholarship@Cornell Law: A Digital Repository. It has been accepted for inclusion in Cornell Law Faculty Publications by an authorized administrator of Scholarship@Cornell Law: A Digital Repository. For more information, please contact jmp8@cornell.edu. 


\section{VIRGINIA LAW REVIEW}

\begin{tabular}{lll}
\hline \hline VolUME 58 & AprI 1972 & Number 4 \\
\hline
\end{tabular}

\section{A COMMENT ON TRIAL-TYPE HEARINGS IN NUCLEAR POWER PLANT SITING}

\section{Roger C. Cramton*}

One of the curious aspects of the contemporary scene is that the use of formal evidentiary hearings in administrative decision-making is expanding rapidly in some fields of public life while it is simultaneously under vigorous attack in other areas. Judicial decisions and a growing body of statutes are bringing trial procedures for the first time to the enclaves of privilege, grant, and largesse that from time immemorial have been handled by informal procedures and governed by concepts of official discretion. ${ }^{1}$ The grant of parole, ${ }^{2}$ eligibility for or termination of welfare, ${ }^{3}$ entitlement to public housing or other benefits, ${ }^{4}$ and the

- Chairman, Administrative Conference of the United States; formerly, Professor of Law, University of Michigan.

This Comment is an elaboration of remarks prepared for delivery at the ALI-ABA Course of Study on "Atomic Energy Licensing and Regulation" at the Shoreham Hotel, Washington, D.C., on November 12, 1971. The views expressed herein are solely those of the author and should not necessarily be attributed to the Administrative Conference of the United States.

The author acknowledges a strong indebtedness to Barry B. Boyer in the preparation of this Comment. Needless to say, Mr. Boyer is not responsible for the stubbornness in which I have persisted in my own views (and errors).

1 See generally O'Neil, Of Justice Delayed and Justice Denied: The Welfare Prior Hearing Cases, 1970 Sup. CT. Rev. 161; Van Alstyne, The Demise of the Rights-Privilege Distinction in Constitutional Law, 81 HARv. L. REv. 1439 (1968); Reich, Individual Rights and Social Welfare: The Emerging Legal Isstees, 74 YALE L.J. 1245 (1965); of. Saferstein, Non-reviewability: A Functional Analysis of "Committed to Agency Discretion," 82 HARv. L. Rev. 367 (1968).

2 See Monks v. State Board of Parole, 58 N.J. 238, 277 A.2d 193 (1971); Comment, The Parole System, 120 U. PA. L. Rev. 282 (1971). See also Johnson, Federal Parole Procedures (Report to the Committee on Informal Actions of the Administrative Conference of the United States, Jan. 1, 1972). A major challenge to the procedures used in granting or denying parole to federal prisoners is now pending. Childs v. United States Board of Parole, Civil Action No. 1616-70 (D.D.C. 1972).

8 See, e.g., Richardson v. Wright, 40 U.S.L.W. 4232 (U.S. Feb. 24, 1972); Goldberg v. Kelly, 397 U.S. 254 (1970).

^ See Thorpe v. Honsing Authority of the City of Durham, 386 U.S. 670 (1967); Holmes v. New York City Housing Authority, 398 F.2d 262 (2d Cir. 1968). 
award of grants ${ }^{5}$ provide many examples of the rapid expansion of the lawyers' bag of tricks into areas in which trial techniques had no application until the last few years.

At the same time the heavy reliance on the formal adjudicatory model on the part of a number of older regulatory agencies has given rise to criticism. Trial-type procedures, it is argued, are not well adapted to the broad investigations of social, economic, and scientific fact and policy that are required in order to set rates in regulated industries, to determine appropriate levels of competition, to monitor the introduction of new technology, or to protect the public from unsafe products or harmful commercial practices. ${ }^{6}$ The judicialization of regulatory functions, many feel, results in long delays, enormous expense to public and private participants, and, ultimately, a poor result. ${ }^{7}$

Perhaps the contradiction inherent in these developments is more apparent than real. The issue in the former situations involving such matters as parole, welfare, grants, and benefits is one of some procedure rather than little or none. When the attack on the existing order must be made in the courts in terms of constitutional "due process," it is not surprising that the lawyer's familiarity with and fondness for adversary hearings, cross-examinations, and the rules of evidence will loom larger than life. The increasing frequency and importance of the encounters of individuals with the officials of the welfare state is a central problem of the rule of law in our time. ${ }^{8}$ Hopefully it is one in which the accumulation of experience with the dynamic qualities of procedural systems

5 See generally Administrative Conference Recommendation No. 26-Minimum Procedures for Agencies Administering Discretionary Grant Programs, 1970-71 REPORT of the Administrative Conference of the United States 58; Tomlinson and Mashaw, The Enforcement of Federal Standards in Grants-in-Aid Programs: Suggestions for Beneficiary Involvement, 58 VA. L. REv. 600 (1972).

${ }^{6}$ See, e.g., R. Noll, Reforming Regulation: An Evaluation of the Ash Council Proposals (1971); W. Gellhorn, Administrative Procedure Reform: Hardy Perennial, 48 A.B.A.J. 243 (1962); Hector, Problems of the CAB and the Independent Regulatory Commissions, 69 YALE L.J. 931 (1960).

7 E.g., R. Noll, supra note 6; Donahue, Lawyers, Economists, and the Regulated Industries: Thoughts on Professional Roles Inspired by Some Recent Economic Literature, 70 Mich. L. Rev. 195 (1971).

8 [A]s social justice becomes a conscious end of state policy there is a vast and inevitable increase in the frequency with which ordinary citizens come into a relationship of direct encounter with state powerholders. The citizen's significant encounter now is not with the policeman or the criminal magistrate but with the official representing a regulatory authority, an administration of social insurances, or a state-operated economic enterprise. It is this dramatically increased incidence of encounter that sets the task of the rule of law in the welfare state.

Jones, The Rule of Law in the Welfare State, 58 Colum. L. REv. 143, 153 (1958). 
will ultimately lead to procedures, highly acceptable to the individuals affected, that allow determinations to be made quickly and accurately and that do not consume inordinate public and private resources in the handling of millions of individual claims. ${ }^{9}$ Whether or not a rational procedural system meeting these requisites will include a heavy reliance on trial-type proceedings, with lawyers dominating the decision-making process, is still an open question.

The requirements of mass justice in the welfare state, however, is another topic for another day; the question of what procedures should be employed by government in the decision of public controversies, of course, has proportions of such heroic dimensions that it is best left to someone more equal to the task. The subject of this Comment is the inquiry into the appropriate use of the trial-type hearing in administrative decision-making. Even the narrower question of whether trialtype hearings are a useful or desirable means of deciding complicated issues of scientific, economic, or social fact and policy is a formidable one, but a start must be made at some point. The use of illustrations drawn from a single field, that of atomic energy licensing and regulation, may assist in sharpening the focus while narrowing the field even further.

Before considering what role trial-type hearings can usefully play in nuclear power plant proceedings, we need to look briefly at the advantages and disadvantages of trial-type proceedings generally and the values we seek to achieve through any hearing process.

\section{Characteristics of Trial-Type Hearings}

Trial-type procedure-i.e., adjudication-is one of several general forms of investigating and deciding problematic situations. ${ }^{10}$ The other common means are various forms of management and of decision-byconcord, such as mediation. Adjudication may be defined as a process in which the affected parties are guaranteed a right to participate through the presentation of proofs and reasoned argument, and in which a decision is made by rationally applying general principles to particular

9 Alfred Conard has borrowed from economics the prefixes "micro" and "macro" to distinguish between justice which is concerned solely with the just result of an individual case and justice which takes the aggregative or system approach of looking at the total consequences of a legal rule or a series of decisions. Conard, Macrojustice: A Systematic Approach to Conflict Resolution, 5 GA. L. Rev. 415 (1971).

10 See generally Boyer, $A$ Re-evaluation of Administrative Trial-Type Hearings for Resolving Comiplex Scientific and Economic Issues 3-23, 32-44 (Staff Report to the Chairman of the Administrative Conference of the United States, Dec. 1, 1971). 
facts. ${ }^{11}$ The managerial model differs from adjudication by virtue of the fact that the decision-maker rather than the parties controls the course of the proceeding; ${ }^{12}$ and mediation, while characterized by party participation, does not rely on a reasoned apphication of principle in reaching a decision. ${ }^{13}$

The essentials of trial-type procedure are well understood. They involve (1) the special characteristics of the tribunal, which should be impartial and competent; ${ }^{14}$ (2) the right of the parties to participate through special procedural devices, such as entitlement to notice, opportunity to present proof and to cross-examine opposing witnesses, and the like $;^{15}$ (3) a special requirement that the decision be based on the record, consistent with accepted principle and rationally explained; ${ }^{\mathbf{1 6}}$ and (4), as a means of enforcing the other requirements, reviewability of decisions by an appellate court. ${ }^{17}$

The paradigm for the use of the trial as a decision-making technique is the criminal or civil case in which the defendant is charged with violating pre-existing legal standards. Although the characteristics of such cases are familiar, several are worth brief mention. First, the controversy is two-sided in nature, with the adversaries taking opposing positions on the issues. Second, the facts generally are within the control or knowledge of the parties and arise out of non-recurring past events. Third, the issues are bipolar in that they call for a "yes" or "no" answer. Fourth, the court is impartial and is called upon to decide a limited number of questions that are usually within the common understanding of the average judge.

\footnotetext{
11 Lon Fuller, The Forms and Limits of Adjudication 11 (unpublished mimeograph).

- 12 See, e.g., Hector, supra note 6, at 632-33; cf. Mentschikoff, Commercial Arbitration, 61 Colum. L. Rev. 846, 847-48 (1961).

13 See Fuller, Collective Bargaining and the Arbitrator, 1963 Wisc. L. Rev. 3, 23; Mentschikoff, The Significance of Arbitration-A Preliminary Inquiry, 17 LAw \& Contempt. Prob. 698 n.1; Fuller, Mediation-Its Forms and Functions, 44 So. Calir. L. REv. 305 (1971).

14 See, e.g., Cinderella Career \& Finishing Schools, Inc. v. FTC, 425 F.2d 583, 589-92 (D.C. Cir. 1970); American Cyanamid Co. v. FTC, 363 F.2d 757 (6th Cir. 1966); Gilligan, Will \& Co. v. SEC, 267 F.2d 461 (2d Cir.), cert. denied, 361 U.S. 896 (1959).

15 E.g., Goldberg v. Kelly, 397 U.S. 254 (1970); Greene v. McEIroy, 360 U.S. 474 (1959).

16 E.g., Thompson v. City of Louisville, 362 U.S. 199 (1960); Environmental Defense Fund, Inc. v. Ruckelshaus, 439 F.2d 584, 597-98 (D.C. Cir. 1971); Holmes v. New York City Housing Authority, 398 F.2d 262 (2d Cir. 1968). See also H. FriendLy, The Federal Administrative Agencies: The Need for Better Definition of Standards (1962).

17 The history and function of judicial review are traced in L. Jaffe, Judictal Control of Administrative Acrion 320-94 (1965).
} 
The shift in focus from the common law court to the administrative agency invariably involves some stress on the adjudicatory model. The agency has broader powers and multiple functions, and it is not expected to act as a passive umpire presiding over a private dispute. It has a program and policies that it is expected to carry out. The proceeding, instead of focusing on non-recurring past events, will often be concerned with the prediction of future effects or consequences. The issues may be far more numerous and interrelated than in an automobile negligence case, for example, and they may not be easily cast in a bipolar form conducive to a "yes" or "no" answer. The balancing of competing values-how much is too much considering the vagaries of an uncertain technology in an uncertain future-is likely to be the crux of the controversy. ${ }^{18}$ And as the issues broaden, the number of persons and groups that are affected, or that may be affected depending upon how subsidiary issues are decided, multiplies rapidly. ${ }^{10}$ The participants, each with a varying pattern of views on the issues and sub-issues, become numerous, and the proceeding loses the two-sided adversary form characteristic of most courtroom litigation. At the extreme, the trial may involve issues of such enormous breadth, complexity, and interrelationship that the case loses all form and structure except as a firm presiding officer or a dominant party, perhaps the agency's staff, gives it shape.

The trial-type hearing, when compared with other forms of decision-

18 Decisions of complex questions must always be made in a situation of partial uncertainty. The determination by the Food and Drug Administration whether to certify a new prescription drug for use must often be made on the basis of a limited showing of beneficial effect by the drug company and an even more limited showing of possible negative effects or contraindications. When policymakers must extrapolate to ordinary use by humans the data developed when massive doses of a drug are administered to mice, the range of expert opinion, and lack of certainty concerning the validity of any given opinion, is pronounced. For a general discussion of the problems of public decision-making in conditions of scientific uncertainty, see NATIONAL ACADEMY of SCIENCES, Technologx: Processes of Assessment and Choice (1969).

19 The decline of the standing doctrine as a barrier to participation in administrative proceedings or judicial review thereof occurred first in the large regulatory controversies of a "polycentric" character, in part because it was so painfully obvious that many persons were affected in varying degrees by agency decisions of this character. The broadening of the standing notion is closely related to the breadth of the proceeding and its possible consequences. See generally Association of Data Processing Serv. Orgs. v. Camp, 397 U.S. 159 (1970); Comment, Judicial Review of Agency Action: The Unsettled Law of Standing, 69 Mrch. L. Rev. 540 (1971); E. Gellhorn, Public Participation in Administrative Hearings 10-17 (Report Prepared for the Committee on Agency Organization and Procedure of the Administrative Conference of the United States, Oct. 29, 1971). 
making, has both advantages and disadvantages, depending upon the purposes to which it is put. The advantages may be found in the special opportunities for party participation, especially those of presenting evidence and cross-examining opposing witnesses. The enforced rationality and conclusiveness of adjudication are also important virtues. On the other hand, the issues must be severely conipressed and put in a bipolar form. Since trial procedure is intricate and specialized, lawyers come to dominate the decision-making process even though many issues may be non-legal. Moreover, trial procedures are enormously expensive and often dilatory. Finally, since the adjudicator is purporting to decide only the case before him, he may be less concerned with the long-run consequences of the decision or of a series of decisions. The focus on "justice in the individual case" does not lend itself to intelligent forward planning, to rational consideration of major options and alternatives, and to a concern for the aggregate effects of individualized decisions.

Nevertheless, the fact is that Congress has provided that much administrative regulation be performed through the medium of trial-type hearings. ${ }^{20}$ This has been due partly to historical accident, partly to concern for the need to control bureaucratic power, and partly to the pressure of interests that had much to gain by the use of elaborate trial procedures. While trials work well, for example, when a license is being revoked or an alien deported on the basis of past culpable conduct, ${ }^{21}$ this reliance on litigious methods has been criticized, particu-

20 In a number of instances, Congress has provided that agency rules of general applicability must be promulgated through formal evidentiary hearings. See generally Hamilton, The Imposition of Trial-Type Procedures in Administrative Rulemaking (Report prepared for the Committee on Rulemaking of the Administrative Conference of the United States, March 9, 1972). In addition, trial-type hearings are used in a wide variety of economic regulation involving resource allocation, ratemaking and entry regulation. A few examples are ICC determinations of the reasonableness of the rates charged by common carriers, 49 U.S.C. $\$ 316(\mathrm{e})$ (1970); CAB grant of certificates to engage in air transportation, 49 U.S.C. $\$ 1371$ (1970); and FCC resolution of contested applications for a broadcast license, 47 U.S.C. $\$ 309$ (d) (1970).

21 For example, 15 U.S.C. $\$ 780$ (b) (4) (1970) enipowers the Securities and Exchange Commission to "censure, deny registration to, suspend for a period not exceeding twelve months, or revoke the registration of, any broker or dealer" in certain circumstances after notice and opportumity for hearing.

The statutory provision governing procedures used in determining deportability of aliens, \& U.S.C. $\$ 1252$ (b) (1970), provides that the Attorney General must pronulgate regulations including requirements that:

(1) the alien shall be given notice ... of the nature of the charges against him and of the time and place at which the proceeding will be held;

(2) the alien shall have the privilege of being represented ... by ... counsel ...;

(3) the alien shall have a reasonable opportunity to examine the evidence against 
larly in situations in which complex issues of economic, scientific, and social policy must be considered, the range of alternative solutions is vast, and a wide variety of interacting interests will be affected-such as in air route licensing by the $\mathrm{CAB}^{22}$ or the formulation of food standards by the FDA. ${ }^{23}$

\section{Criteria for Evaluating Procedures}

An initial problem is to determine by what standards a given procedure should be judged. What are the criteria for evaluating procedural systems?

Procedures, for the most part, are a means to an end-the accomplishment of social purposes. But at the same time procedures in themselves may create or destroy important values. The usual statement of these values, in terms of "fairness," "due process," and the like, suffers from undue generality, since the content of these value-laden words shifts from time to time and from person to person.

The distinction between rulemaking and adjudication also provides little help. While the idea that trials are appropriate only for "adjudicative facts" is suggestive, ${ }^{24}$ it begs the hard question because the identification of "adjudicative facts" is so subjective and flexible. ${ }^{25} \mathrm{We}$ are reduced to a basic notion that in a society committed to a representative form of government, private persons should have a meaningful opportunity to participate in government decisions which directly affect them, especially when governmental action is based on individual rather than on general considerations. ${ }^{26}$

him, to present evidence in his own behalf, and to cross-examine witnesses presented by the Government; and

(4) no decision of deportability shall be valid unless it is based upon reasonable, substantial, and probative evidence.

Intervention and participation by "public interest lawyers" in proceedings of such a narrow and quasi-criminal character, otler than in the form of an amicus brief, is unlikely to be permitted. See Cramton, The Wby, Where and How of Broadened Public Participation in the Administrative Process, 60 Geo. L.J. 525 (1972).

${ }^{22}$ See generally Jones, Licensing of Domestic Air Transportation by the Civil Aeronautics Board, (Report for the Committee on Licenses and Autlorizations of the Administrative Conference of the United States, Sept. 1962).

${ }^{23}$ See Hamilon, Rulemaking on a Record by the Food and Drug Administration (Report prepared for the Administrative Conference of the United States, Sept. 1971).

$241 \mathrm{~K}$. Davis, Adminstrative Law Treatise 413-14 (1958). See also Davis, The Requirement of a Trial-Type Hearing, 70 HaRv. L. Rev. 193 (1956).

25 Robinson, The Making of Administrative Policy: Anotber Look at Rulemaking and Adjudication and Administrative Procedure Reform, 118 U. PA. L. Rev. 485, 52122, 536 (1970).

${ }^{26}$ It remains uncertain under Goldberg v. Kelly, 397 U.S. 254 (1970), what degree 
Beyond the fundamental principle of meaningful party participation, any evaluation of administrative procedures must rest on a judgment which balances the advantages and disadvantages of each procedural system. In striking this balance, I believe that the following formulation of competing considerations is more helpful than "fairness" or "due process": the extent to which the procedure furthers the accurate selection and determination of relevant facts and issues, the efficient disposition of business, and, when viewed in the light of the statutory objectives, its acceptability to the agency, the participants, and the general public.

The first consideration, accuracy, serves as a short-hand reference to the rational aspects of a decision-making process. The ascertainment of truth, or, more realistically, as close an approximation of reality as human frailty permits, is a major goal of most decision-making. There are better and worse ways, in various contexts, of gathering relevant information, selecting or formulating controlling principles, and applying the correct principles to the probable facts. Accuracy, moreover, is not only a facet of each case but an aggregative or system characteristic of uniform and consistent results that give equal treatment to similarly situated persons. Accurate results in a particular instance ("justice in the individual case") may be less important in many areas than a high degree of consistency in the decision of a large number of cases.

The second consideration, efficiency, emphasizes the time, effort, and expense of elaborate procedures. The work of the world must go on, and endless mit-picking, while it may produce a more nearly ideal solution, imposes huge costs and impairs other important values. In the polycentric administrative case, the efficiency of trial procedures meets the severest test. This criterion, unlike the others, is capable of quantitative statement since time and effort may usually be stated in dollar terms. Concern with public costs and expenditures must not be allowed to

of participation by the affected person is required by due process and the extent to which trial procedures must be provided. As the Court observed in Goldberg, participatory rights must be assessed in terms of the conflicting interests of government and citizen in each situation: "The extent to which procedural due process must be afforded the recipient is influenced by the extent to which he may be condemned to suffer grievous loss,' . . . and depends upon whether the recipient's interest in avoiding that loss outweighs the governmental interest in summary adjudication." 397 U.S. at 262-63. The Court recently had an opportunity to illuminate the Goldberg rationale as it applied to the Social Security disability program, but instead of examining the question in detail the majority remanded for further consideration in light of new regulations promulgated by the Secretary of HEW. Richardson v. Wright, 40 U.S.L.W. 4232 (U.S. Feb. 24, 1972). 
obscure the fact that the private costs of administrative delay are usually far higher than the total of governmental costs. ${ }^{27}$

The final consideration, acceptability, emphasizes the indispensable virtues of procedures that are considered fair by those whom they affect, as well as by the general public. ${ }^{28}$ Usually this translates into meaningful participation in the decisional process. The authority of decisions in a society resting on the consent of the governed is based on their general acceptability. Moreover, if procedures are deemed fair by those immediately affected, their cooperation and assistance can be obtained, with the result that administrative action will be better informed and thought out.

\section{Trial-Type Hearings in Atomic Energy Licensing}

Atomic energy licensing and regulation involve the kinds of issues that place considerable strain upon trial-type hearings. The determination, for example, of whether an atomic reactor is designed with sufficient safety devices or will adversely affect the environment involves issues that require substantial input from experts of diverse disciplines: engineers, scientists, economists, and ecologists. The basic issues are economic and political in character, since they involve trade-offs affecting the allocation of scarce resources. Since increased safety of atomic reactors costs money, and since it is probably impossible to make them absolutely safe, the decision regarding the protective features that should be required involves a determination that some level of risk is acceptable in view of the costs of greater safety. Similarly, preservation of the scenic beauty or ecology of a power plant site, or alternative siting, usually will cost more, thus posing a question of finding the point at

27 See P. MacAvoy, The Effectiveness of the Federal Power Commission (reprint issued by the Brookings Institution, 1971).

28 There is a tendency on the part of lawyers to think of acceptability in terms of traditional patterns of legal thinking. Since lawyers have valued and enjoy adversary proceedings, it is assumed that members of the public also feel the same way. This assumption, however, is questionable. The issue is one of the acceptability of procedures to the persons affected and not to any group of professionals in the community. The views of professionals may be relevant when they will inevitably be involved, but the reference should not be to lawyers alone. In disability evaluations, for example, involving inputs of a medical, occupational, and legal character, the views of doctors concerning methods that produce accurate determinations in an expeditious, inexpensive and acceptable manner are as relevant as those of lawyers. Just as war is too important to be left to the soldiers, justice is so important that it should not be left to the desires (and profits?) of lawyers. For a useful discussion of the ways in which decision-making techniques can exclude noulawyers from the decisional process; see Donahue, supra note 7. 
which the cost of additional protection for the environment becomes too great. In deciding these safety and environmental questions, the AEC must deal with a variety of specialists of relatively narrow expertise, a vast array of alternative choices and potentially affected interests, very rudimentary standards of decision, and a lack of reliable data from which to extrapolate future conditions.

Within a given project the trade-offs that are necessary may be placed on a continunm of increasing generality and at some point raise issues that should be decided by the political process. Thus, in the reactor-licensing context there may be a narrow, rather technical question of whether a more expensive welding technique should be required to assure greater safety in the cooling system; a middle-range issue of whether radiological pollution which would affect an adjacent stream is acceptable or should be reduced at greater cost; and a broad policy problem of whether the aggregate restrictions imposed on the plant will cause power supplies to turn to fossil fuel equipment, with the environmental and economic consequences that would follow from that decision. At some fairly early point in this progression, decisions should be made not by experts, administrators, or by reviewing judges but by the elected representatives of the people.

Measured against these needs, how do the procedures stand up? The current AEC licensing process is complex and multi-layered. ${ }^{29}$ In brief outline, it begins with a period of bargaining between the AEC staff and the applicant. After agreement on the important features of the application for a construction permit is reached, the staff prepares a report which is reviewed by the Advisory Committee on Reactor Safeguards, a fifteen-man panel comprised of techmical specialists from outside the Commission. The ACRS review is conducted at informal, non-public, non-record conferences, although staff and occasionally representatives of the applicant attend to iron out differences. The ACRS issues a conclusory report to the Commission, either favoring or opposing the proposed reactor.

A trial-type hearing is then held in the vicinity of the reactor site, regardless of whether there are any contested safety issues. At issue are all of the questions previously considered at the informal, non-public stage. For the first time, however, environmental and citizen groups are

29 For a more complete description of the AEC licensing process, see Ellis \& Johnston, Licensing of Nuclear Power Plants by the Atomic Energy Commission, reprinted in Hearings on AEC Licensing Procedure and Related Legislation Before the Subcomm. on Legislation of the Joint Comm. on Atomic Eniergy, 92d Cong., Ist Sess., pt. 2, at 581 (1971). 
permitted to participate. The decision-making body at this hearing is the Atomic Safety and Licensing Board, which consists of two technically qualified personnel and a chairman "qualified to conduct administrative proceedings." If the Board's initial decision is favorable, construction may begin-regardless of whether review is sought before the Atomic Safety and Licensing Appeal Board and the Commission. A similar system of informal review talkes place when construction has been completed and the applicant seeks an operating license. In addition, a full-blown hearing may be held at this point if a contest has developed.

The most important phase of the decision-making process in AEC licensing is the stage preceding issuance of the construction permit, which is characterized by exchange of information, negotiation, and bargaining between the AEC staff, the applicant, and the ACRS. This is so for a number of reasons. Once construction has commenced, any change of plans, "baclffitting," or delay imposes enormous costs on the utility applicant and ultimately its customers. Moreover, the dynamics of the process tend to magnify the importance of the investigation and bargaining stage that precedes the hearing.

The importance of the informal stage has several significant consequences. On the one hand, the staff has a virtual veto power during negotiations, since in practice applicants will not persist into later stages of the proceeding without staff approval. On the other hand, potential opponents of the plant design or siting, who are excluded at the earlier stages, tend to view the hearing stage as a stacked deck because the staff, the applicant, and the ACRS present a united front, with the result that questions that have previously been debated during negotiations are minimized during the hearing. With the growing number and increasing sophistication of public intervenors, this situation seems likely to result, as one critic has said, in "an artificial and distrustful atmosphere for the licensing process" in which intervenors resort "to the tactic of delay rather than plotting a strategy for victory." 30

In other words, the licensing process seems to be losing acceptability among environmental and citizen groups. The result may be that their dissatisfaction with the process will lead them to resort to procedural devices that delay the outcome and that force concessions by utility apphicants as the price of abandoning the fight. A procedural system that allows results to be determined by the leverage which procedure provides to persistent contestants is a modern-day version of ordeal by

30 See id. at 556 . 
battle. ${ }^{31}$ The loss of efficiency and acceptability resulting from pro: longed trial-type hearings at two stages has also spread disillusionment among the utility applicants and equipment manufacturers. We are approaching a situation in which everyone involved is unhappy.

- One obvious proposal would be to abandon public hearings at the operating-license stage, or at least to impose a high burden of proof on intervenors before the hearing requirement was triggered. This could be done on the assumption that most issues relating to the plant design or site have been litigated at the construction permit stage and that two bites at the apple should not be allowed. ${ }^{32}$

Elimination of the trial-type hearing at the construction permit stage seems a more hazardous prescription. This might increase the doubts that environmental groups have about the acceptability of the licensing process; in addition, there is the further risk that it might impair accuracy as well, with consequences that are too awesome to contemplate. The AEC's licensing process is already more heavily dominated by scientists and technicians than most administrative proceedings. While many of the issues raised during a licensing proceeding are largely technical, it is by no means clear that all of them are; trade-offs involving value questions of relatively broad social impact must be made, and it seems doubtful whether it is wise to consign these problems to the exclusive sphere of scientists and specialists. Policy issues should not be passed off as scientific problems, but should be faced forthrightly as such.

The maintenance of public confidence in the licensing process argues in favor of opening it to the greatest possible public scrutiny and input, a position that, carried to its logical extreme, would call for opening up the bargaining process. I do not know whether this is feasible or how it could be accomplished, but it is a possibility that should be considered.

31 Occasionally vociferous public opposition to a proposed nuclear power plant has caused utilities to withdraw their applications; see,ee.g., D. NeLkiN, Nuctear Power and Its Critics: The Cayuga Lake Controversy (1971); Green, "Reasomable Assurance" of "No Undue Risk," Scientist \& Citizen, June/July 1968, at 128, 134.

32 The AEC has recently proposed legislation which would provide for legislativetype hearings at the operating license stage in place of the current trial-type hearings, and would specify that this hearing, would be available only when "a prima facie showing has been made by a person whose interest may be affected by the proceeding that, as a result of a significant advance or change in the technology occurring after the most recènt licensing action in the proceeding, addition, elimination or modification of structures, systems or components of the facility will provide substantial, additional protection" for safety or the environment. H.R. 13731, 92d Cong., 2d Sess. '(1972). 
The introduction of third parties into the early informal stage could complicate the regulatory process rather considerably, with intervening parties favoring either the staff or the applicant, or taking a wholly different position. If rights to participate in a relatively unstructured bargaining process were accorded, would the lack of structure give disproportionate strength to those with the most resources or to those who were most intransigent? More detailed knowledge about the mechanics and dynamics of the negotiating process seems necessary before any predictions can be made.

An alternative to providing plenary third-party participation in the negotiating process, which has been suggested by some critics, is to provide for such participation episodically, through a series of public conferences punctuating the basic two-party negotiations. Whether such a device would work effectively seems debatable. One key factor would seem to be timing the conferences so that they would correspond with important decision points in the bargaining process. If they were held too early, before the issues were drawn, they would probably have all the difficulties of unrestricted bargaining, complicated by the inhibitions inherent in being on the record; if they were held too late, after a de facto decision had been reached, they could be criticized as mere window dressing.

A third approach would be to push public participation back into even earlier stages, into the planning process itself. Proposals for greater reliance on rulemaking procedure as a method of formulating general policy would have this effect. The gap between promise and performance when it comes to broader use of rulemaking as a regulatory technique is a large one. If the state of the nuclear art now permits the approval of standardized designs or matters of similar import in general rulemaking proceedings, however, this approach may yield dramatic results in terms of more and better decisions arrived at more quickly.

The AEC is currently conducting two major rulemaking proceedings ${ }^{33}$ which should provide valuable insight into the possibilities of resolving complex scientific issues on a generic basis. The first of these proceedings deals with formulation of acceptance criteria for emergency core cooling systems, which are safety features designed to keep the heat in a reactor core from exceeding permissible tolerances in the event of a failure in the primary cooling system; the other proceeding con-

33 The procedural rules governing the two proceedings are set forth in 36 Fed. Reg. 22774-75 (Nov. 30, 1971), and were revised by a supplemental notice issued in 37 Fed. Reg. 287-89 (Jan. 8, 1972). 
cerns the establishment of standards for the discharge of radioactive effluents from nuclear power plants. In many respects, the procedures used in these rulemaking proceedings resemble licensing adjudications; for example, a three-man hearing panel similar to an Atomic Safety and Licensing Board presides, a verbatim record is kept, cross-examination is permitted, and in general the course of the proceeding is similar to a licensing hearing. However, discovery is sharply limited in comparison to a licensing proceeding, and the hearing board will not issue an initial decision or proposed rule. In large measure, the close resemblance of these rulemaking procedures to licensing hearings may result from the fact that the need for a broad-scale review of the ECCS and effluents problems first became apparent in contested licensing hearings; thus, the rulemaking is in many respects like a consolidation of these individual licensing proceedings. In the future, it may be possible for the Commission to experiment with less formal rulemalking proceedings as a means of simplifying these complex safety questions.

Legislative proposals that would require general questions of power plant authorization and siting (Do we need more power? What fuel sources should be used and in what proportions? Where, in general, should the needed plants be located?) to be handled as part of a longrange planning process are receiving much discussion today. ${ }^{34}$ There are a number of unanswered questions with respect to such proposals: At what level of government, and by what agencies and procedures, are the basic decisions to be made? What devices will be employed to prevent the reopening of these questions in subsequent licensing proceedings of a more individualized character? Is the proliferation of agencies and approvals at each level of government-local, state and federal-merely going to add more layers and steps to a process that is already labyrinthine and Byzantine? Can we afford the "government by impasse" that is the likely result of giving each agency and each level of government a power of veto on any power plant project? Some fundamental issues of decision-making in a federal republic need to be resolved before the present confusion will be brought under control.

Pushing issues back into an early planning process also makes it diffcult for affected interests to know when and how to participate. The more generalized the discussion, the less each individual can recognize

34 See, e.g., H.R. 605, 92d Cong., 1st Sess. (1971); H.R. 277, 92d Cong., 1st Sess. (1971); Hearings on Power Plant Siting and Environmental Protection Before the Subcoirim. on:Communications and Power of the House Comm. on Interstate and. Foreign Commerce, 92d Cong., 1st Sess. (1971). 
that his interests are involved or that it is worthwhile advancing them. Existing statutory provisions governing atomic energy licensing require a public hearing even in uncontested cases. The statute is premised on the theory that public notice is particularly important and that a public hearing is more likely to provide actual notice than the initiation of planning. Furthermore, Calvert Cliffs $s^{35}$ and similar cases $^{36}$ indicate that the courts may be disinclined to accept procedures involving advance planning as a substitute for the AEC's duty to make an independent assessment of the public interest, through hearings if necessary, absent a clear and unambiguous statutory limitation on scope of review. ${ }^{37}$

The administrative process huffs and puffs; and small armies of lawyers and regulators engage in heated and lengthy battles. Yet I sometimes wonder whether these time-consuming and expensive regulatory controversies should be viewed as rational techniques of decisionmaking or as tribal rites. I believe that confusion has reigned long enough on the field of atomic energy licensing and other vital areas affected by agency decisions. Fortunately, there are growing signs of reconsideration and impending change. We can and must improve the procedures for reaching decisions in these important areas. The conflict between full consideration and timely resolution of important issues must be resolved through the use of procedures that reach accurate results, are efficient and are acceptable to those affected and the general public.

35 Calvert Cliffs' Coordinating Committee v. AEC, 449 F.2d 1109 (D.C. Cir. 1971).

36 E.g., Greene County Planning Board v. FPC, 40 U.S.L.W. 2522 (2d Cir. Jan. 17, 1972); Natural Resources Defense Council v. Morton, 40 U.S.L.W. 2497 (D.C. Cir. Jan. 13, 1972); Kalur v. Resor, 40 U.S.L.W. 2391 (D. Colo. Dec. 21, 1971).

37 For further discussion of some of the problems agencies may face if they are required to consider all possible alternatives in trial-type hearings and reach an "optimally beneficial decision," see Cramton \& Berg, On Leading a Horse to Water: NEPA and the Federal Bureaucracy, 18 PRACTICAI LAWYER - (1972). 